\title{
Vitamin D receptor gene polymorphisms and musculoskeletal injuries in professional football players
}

\author{
MYOSOTIS MASSIDDA ${ }^{1}$, LAURA CORRIAS ${ }^{1}$, VALERIA BACHIS ${ }^{1}$, PAOLO CUGIA ${ }^{2}$, \\ FRANCESCO PIRAS ${ }^{2}$, MARCO SCORCU $^{2}$ and CARLA M. CALÒ ${ }^{1}$ \\ ${ }^{1}$ Department of Life and Environmental Sciences, University of Cagliari; \\ ${ }^{2}$ FMSI CR Sardegna and Cagliari Calcio SpA, Cagliari 09100, Italy
}

Received July 9, 2014; Accepted February 9, 2015

DOI: $10.3892 / \mathrm{etm} .2015 .2364$

\begin{abstract}
The aim of the present study was to investigate the association between vitamin D receptor (VDR) gene polymorphisms and musculoskeletal injury (MI) in elite football players. In total, 54 male professional football players were recruited from an official Italian professional championship team between 2009 and 2013. The cohort was genotyped for the ApaI, BsmI and FokI polymorphisms and MI data were collected over four football seasons. No significant differences were identified among the genotypes in the incidence rates or severity of $\mathrm{MI}(\mathrm{P}=0.254)$. In addition, no significant associations were observed between VDR polymorphisms and MI phenotypes $(\mathrm{P}=0.460)$. However, the results of the casewise multiple regression analysis indicated that the ApaI genotypes accounted for $18 \%$ of injury severity $(\mathrm{P}=0.002)$. Therefore, while the BsmI and FokI polymorphisms did not appear to be associated with the severity or incidence of MI, the ApaI genotypes may have influenced the severity of muscle injury in top-level football players.
\end{abstract}

\section{Introduction}

The vitamin D receptor (VDR) gene is located on human chromosome 12 (12q12-q14) and is $100 \mathrm{~kb}$ in length, with $>100$ restriction endonuclease cutting site polymorphisms (1). VDR is a member of the steroid superfamily of nuclear receptors, which serve key functions in the regulation of the transcriptional activity of the vitamin D metabolite 1 $\alpha, 25$-dihydroxy vitamin D3. Vitamin D performs an established role in calcium metabolism, increasing the absorption of calcium and phosphate from the intestines and the reabsorption of calcium in the kidneys. Furthermore, vitamin D is hypothesized to be crucial in skeletal muscle function, and VDRs have been identified in this tissue $(2,3)$. In addition,

Correspondence to: Dr Myosotis Massidda, Department of Life and Environmental Sciences, University of Cagliari, S.S. $554 \mathrm{Km}$ 4.500, Monserrato, Cagliari 09100, Italy

E-mail: myosotis.massidda@unica.it

Key words: ApaI, BsmI, FokI, elite athletes, genes, sport vitamin D has been hypothesized to influence myocytes via VDRs, resulting in myocyte proliferation, differentiation, growth and inflammation (4).

The VDR gene contains numerous polymorphisms. A polymorphic start codon in the $5^{\prime}$ end of the gene is identified by the restriction enzyme FokI. There are three polymorphisms at the $3^{\prime}$ end of the VDR gene, generating the BsmI, ApaI and TaqI restriction sites (5).

These functional genetic polymorphisms in the VDR gene may be associated with tissues that respond to vitamin D, including muscle cells and adipocytes. Skeletal muscle is established to be a target organ for vitamin D, and vitamin D metabolites directly affect muscle cell metabolism via a number of pathways (6). Furthermore, previous studies have associated vitamin D deficiency with muscular weakness $(6,7)$.

Numerous cohort and cross-sectional studies have investigated the associations between vitamin D status and various parameters of neuromuscular performance. Prior studies have indicated that vitamin $\mathrm{D}$ exerts a beneficial effect on these parameters (7-10); however, certain other studies have contradicted these findings (11-14).

Muscle injury is a major problem for football players and has been reported to account for $20-37 \%$ of all injury-associated time loss at the male professional level and $18-23 \%$ at the amateur level $(15,16)$. Muscle weakness may be one of the primary factors determining the outcome of athletic injuries (17).

In a published abstract, Shindle et al (18) assessed vitamin D levels and skeletal muscle injuries in 89 professional American football players and observed that players who suffered at least one muscle injury throughout the prior season exhibited significantly lower vitamin D levels compared with players that sustained no muscle injury during the same period. A recent study aimed to assess vitamin D levels in professional American football players and to evaluate the association between vitamin D levels and ethnic group, fracture history, and the ability to obtain a contract position (19). The study indicated that professional football players of African descent exhibit a higher rate of vitamin D deficiency compared with Caucasian players. Furthermore, professional football players with higher vitamin D levels were more likely to obtain a contract position in the National Football League. The authors hypothesized that professional football players deficient in 
Table I. Characteristics of the players by VDR polymorphism and respective genotypes (ApaI: AA, Aa or aa; BsmI: BB, Bb or bb; and FokI: FF, Ff or ff).

\begin{tabular}{lcccc}
\hline Polymorphism & Age (years) & Height $(\mathrm{cm})$ & Weight $(\mathrm{kg})$ & Seasons played (n) \\
\hline ApaI AA & $25.0 \pm 5.3$ & $180.1 \pm 5.6$ & $71.7 \pm 3.7$ & $2.0 \pm 1.0$ \\
ApaI Aa & $25.8 \pm 3.3$ & $184.5 \pm 3.7^{\text {ab }}$ & $76.2 \pm 5.5^{\mathrm{a}}$ & $1.7 \pm 1.0$ \\
ApaI aa & $27.6 \pm 4.3$ & $177.8 \pm 6.2$ & $72.8 \pm 4.2$ & $2.2 \pm 1.2$ \\
BsmI BB & $26.3 \pm 5.4$ & $180.6 \pm 4.8$ & $72.0 \pm 3.6$ & $2.0 \pm 1.2$ \\
BsmI Bb & $25.3 \pm 3.9$ & $184.0 \pm 4.4$ & $75.1 \pm 5.9$ & $1.8 \pm 1.0$ \\
BsmI bb & $26.4 \pm 4.1$ & $180.0 \pm 6.3$ & $73.8 \pm 4.6$ & $2.0 \pm 1.0$ \\
Fok I FF & $25.5 \pm 2.9$ & $180.9 \pm 5.5$ & $73.4 \pm 4.5$ & $1.6 \pm 0.9$ \\
FokI Ff & $27.0 \pm 5.2$ & $181.6 \pm 5.4$ & $73.8 \pm 5.7$ & $2.1 \pm 1.1$ \\
Fok If & $24.5 \pm 4.9$ & $185.4 \pm 4.8$ & $76.0 \pm 5.3$ & $2.2 \pm 1.2$ \\
\hline
\end{tabular}

Data are expressed as the mean \pm standard deviation. ${ }^{\mathrm{a}} \mathrm{P}<0.01$ vs. AA and ${ }^{\mathrm{b}} \mathrm{P}<0.01$ vs. aa. VDR, vitamin $\mathrm{D}$ receptor.

vitamin D level may be at a greater risk of bone fracture. In addition, a number of previous studies have suggested associations between certain genetic markers and the susceptibility of players to injury and performance while participating in sport $(20,21)$. Thus, the performance of professional football players and their susceptibility to injury may be influenced by genetic factors (22-34).

The present study aimed to analyze the associations between the VDR gene polymorphisms FokI, BsmI and ApaI and indirect musculoskeletal injury (MI) rates in professional football players over the course of four competitive seasons.

\section{Materials and methods}

Participants. The sample population contained 54 male professional football players (age, $25.9 \pm 4.3$ years; weight, $73.9 \pm 5.0 \mathrm{~kg}$; height, $181.7 \pm 5.5 \mathrm{~cm}$ ) from an Italian professional championship team. All the subjects were of Caucasian descent for at least three generations. The data for 25 players (46.2\%) were collected between 2009 and 2010; data for 15 players (27.7\%) were collected between 2009 and 2011; and data for 14 players (25.9\%) were collected between 2009 and 2013.

Players trained for $\sim \operatorname{six}$ weeks (two sets of $120 \mathrm{~min}$ per day; five days per week) preseason and $\sim 32$ weeks during the competitive season (520 min per week). Players joining/leaving the cohort were included/excluded from the date of joining/leaving. Players with an existing injury at the start of the study were not excluded from the study; however, their existing injuries were not included in the study. Training exposure was defined as any team-based or individual physical activity, conducted under the control or guidance of the team's coaching and fitness staff, that was aimed at maintaining or improving players' football skills or physical condition. Matches between teams were considered to be training exposure. Any match activity that was a part of a player's rehabilitation from injury was not recorded as match exposure.

Experiments were undertaken with the written informed consent of each participant and the study protocol was approved by the Cagliari Calcio ethics committee (Cagliari, Sardinia). The present study was conducted in accordance
Table II. Reaction mix for PCR analysis, $\mu 1$.

\begin{tabular}{lccc}
\hline Reagent & FokI & ApaI & Bsm \\
\hline Reaction buffer & 2.5 & 3.5 & 1.5 \\
$\mathrm{MgCl}_{2}$ & 0.8 & 3.5 & 0.75 \\
dNTPs $(200 \mu \mathrm{M}$ each $)$ & 1 & 1 & 1 \\
Primer $\mathrm{F}(0.5 \mu \mathrm{M})$ & 0.2 & 0.2 & 0.4 \\
Primer $\mathrm{R}(0.5 \mu \mathrm{M})$ & 0.2 & 0.2 & 0.4 \\
$\mathrm{H}_{2} \mathrm{O}$ & 14.2 & 14.5 & 18.85 \\
Taq polymerase & 0.1 & 0.1 & 0.1 \\
DNA & 2 & 2 & 2 \\
Total volume & 21 & 25 & 25 \\
\hline
\end{tabular}

PCR, polymerase chain reaction; dNTP, deoxynucleotide triphosphate.

with the Declaration of Helsinki for Human Research of 1974 (last modified in 2000).

Study design. Recruitment, genotyping and statistical analyses were performed following the guidelines described in 'replicating genotype-phenotype associations' (35). The study design followed the consensus on definitions and data collection procedures in studies of football injury as outlined in the consensus document (36) and by the Union of European Football Associations (37).

Injury data collection. MI was defined as any physical condition that occurred during practice that prevented a player from participating in training or match play for at least one day following onset (38). Injuries were categorized under four degrees of severity based on the number of days absence incurred: Minimal (code 1), 1-3 days; mild (code 2), 4-7 days; moderate (code 3), 8-28 days; and severe (code 4), $>28$ days. The registration of an MI was based on a clinical examination by the football team medical staff. Ultrasound and magnetic resonance imaging scans were used to morphologically classify the injuries. Time loss due to injury was recorded 
Table III. Injury incidence and severity between VDR genotypes.

A, Injury incidence

\begin{tabular}{|c|c|c|c|c|c|c|c|c|c|}
\hline \multirow[b]{2}{*}{ Parameter } & \multicolumn{3}{|c|}{ ApaI } & \multicolumn{3}{|c|}{ BsmI } & \multicolumn{3}{|c|}{ FokI } \\
\hline & AA & $\mathrm{Aa}$ & aa & $\mathrm{BB}$ & $\mathrm{Bb}$ & $\mathrm{bb}$ & $\mathrm{FF}$ & $\mathrm{Ff}$ & ff \\
\hline $\begin{array}{l}\text { Injury } \\
\text { incidence }\end{array}$ & $0.19 \pm 0.34$ & $0.21 \pm 0.60$ & $0.80 \pm 0.93$ & $0.17 \pm 0.27$ & $0.22 \pm 0.64$ & $0.45 \pm 0.72$ & $0.30 \pm 0.60$ & $0.37 \pm 0.62$ & $0.20 \pm 0.60$ \\
\hline Athletes (n) & 20 & 26 & 8 & 12 & 23 & 19 & 25 & 21 & 8 \\
\hline
\end{tabular}

B, Injury severity

\begin{tabular}{|c|c|c|c|c|c|c|c|c|c|}
\hline \multirow[b]{2}{*}{ Parameter } & \multicolumn{3}{|c|}{ ApaI } & \multicolumn{3}{|c|}{ BsmI } & \multicolumn{3}{|c|}{ FokI } \\
\hline & AA & $\mathrm{Aa}$ & aa & $\mathrm{BB}$ & $\mathrm{Bb}$ & $\mathrm{bb}$ & $\mathrm{FF}$ & $\mathrm{Ff}$ & $\mathrm{ff}$ \\
\hline $\begin{array}{l}\text { Injury } \\
\text { severity }\end{array}$ & $2.62 \pm 1.06$ & $3.2 \pm 0.44$ & $3.6 \pm 0.54$ & $2.4 \pm 1.44$ & $3.25 \pm 0.51$ & $3.33 \pm 0.70$ & $3.25 \pm 0.88$ & $3.11 \pm 0.60$ & $3.0 \pm 0.33$ \\
\hline Athletes (n) & 8 & 5 & 5 & 5 & 4 & 9 & 8 & 7 & 3 \\
\hline
\end{tabular}

Data are expressed as the mean \pm standard deviation. VDR, vitamin D receptor.

on a weekly basis by the medical staff using a standardized injury report form during the preseason and regular season. Structural-mechanical injuries (such as tendon ruptures and total/partial muscle ruptures) and functional injuries (such as fatigue-induced or neurogenic muscle hardening/hypertonia) or cramps, were included in the injury group, whereas contusions and hematomas were excluded. MI incidence was calculated per $1,000 \mathrm{~h}$ of training exposure (training and matches).

DNA analysis. Genomic DNA was extracted from buccal swab samples using a QIAamp DNA Mini Kit (Qiagen GmbH, Hilden, Germany). Extracted DNA was analyzed by quantitative polymerase chain reaction (Gene Amp ${ }^{\circledR}$ PCR System 2720; Applied Biosystems Life Technologies, Foster City, CA, USA) using the primers suggested by Rezende et al (39).

The reaction was performed as reported in the Table I. The running conditions were as follows: Predenaturation at $95^{\circ} \mathrm{C}$ for $5 \mathrm{~min}$, followed by 35 cycles of denaturation $\left(94^{\circ} \mathrm{C}\right.$ for $1 \mathrm{~min})$, annealing $\left(59^{\circ} \mathrm{C}\right.$ for $\left.30 \mathrm{~min}\right)$, extension $\left(72^{\circ} \mathrm{C}\right.$ for $1 \mathrm{~min}$ ) and a final extension at $72^{\circ} \mathrm{C}$ for $5 \mathrm{~min}$.

Amplified products were digested with specific restriction enzymes (FokI, ApaI and BsmI), that generated the following fragments: FokI, 272 bp for the wild-type allele (allele F) or 198 and $74 \mathrm{bp}$ for the polymorphic variant (allele f); ApaI, 740 bp for the wild-type allele (allele A) or 515 and $225 \mathrm{bp}$ for the polymorphic variant (allele a); BsmI, $825 \mathrm{bp}$ for the wild-type allele (allele B) or 650 and $175 \mathrm{bp}$ for the polymorphic variant (allele b). Fragments were separated by electrophoresis in $8 \%$ polyacrylamide gel and visualized by silver staining (15).

Statistical analysis. Analysis of variance (ANOVA) was used to compare genotypes and continuous data. Scheffé post hoc analysis was used to identify significant differences between the three genotypes. Factorial ANOVA was used to examine associations among the three polymorphisms and injury parameters.

Multivariate analysis was used to determine the model that most accurately predicted MI incidence and severity. Factors that were significantly associated with MI incidence (age and height) and severity (min of match exposure) and VDR polymorphisms were included in the model. The Hardy-Weinberg equilibrium was calculated using Genepop software, version 4.0.10 (genepop.curtin.edu.au). Data were analyzed using Statistica software, version 7.0 (StatSoft, Inc., Tulsa, OK, USA).

\section{Results}

Height and weight. The VDR Bsm $(\mathrm{BB}, 22.2 \%, \mathrm{n}=12 ; \mathrm{Bb}$, $42.5 \%, \mathrm{n}=23$; and bb, 35.1\%, n=19), ApaI (AA, 37\%, n=20; Aa, $48.1 \%, \mathrm{n}=26$; and aa, $14.8 \%, \mathrm{n}=8)$ and FokI (FF, 46.3\%, n=25; Ff, $38.8 \%, \mathrm{n}=21$; and ff, $14.8 \%, \mathrm{n}=8$ ) polymorphisms concurred with the Hardy-Weinberg equilibrium $(\mathrm{P}=0.325)$. Age, height, weight and the number of seasons played were not observed to be significantly different between the BsmI $(\mathrm{P}=0.295)$ and FokI ( $\mathrm{P}=0.203)$ genotypes (Table II). However, carriers of the Aa genotype for the ApaI polymorphism exhibited higher height and weight compared with carriers of the AA and aa genotypes $(\mathrm{P}=0.002)$.

Muscle injury. No significant differences were identified in MI incidence/severity between genotypes $(\mathrm{P}=0.254)$ (Table III).

Factorial analysis suggested no significant association between the BsmI, ApaI and FokI polymorphisms and the incidence or severity of $\mathrm{MI}(\mathrm{F}=0.557 ; \mathrm{P}=0.460)$.

The age, height and VDR polymorphisms of the players were assessed for their association with MI incidence. VDR 
polymorphisms and match exposure were assessed for their contribution to MI severity variance using a casewise multiple regression model. The optimum model for $\mathrm{MI}$ incidence, which accounted for $12 \%(\mathrm{P}=0.171$; standard error=2.69) of the variance, included height and age. However, only height $(\mathrm{R} 2 \mathrm{adj}=6.83 ; \mathrm{P}=0.034)$ was significantly associated with the total incidence of injury model. The model for MI severity, which accounted for $28 \%(\mathrm{P}=0.035$, standard error=23.06) of the variance, included the ApaI genotypes and mins of match exposure, but only ApaI genotypes $(\mathrm{R} 2 \mathrm{adj}=18.72 ; \mathrm{P}=0.041)$ contributed significantly to the severity of injury model.

\section{Discussion}

To the best of our knowledge, the present study is the first to analyze the influence of VDR polymorphisms on MI in professional football players.

The results suggested that BsmI and FokI polymorphisms were not associated with MI incidence or severity in elite football players. However, it is possible that the ApaI polymorphism may be associated with the severity of MI. The forward stepwise multiple regression model indicated that the ApaI polymorphism of the VDR gene contributed significantly to the MI severity variance $(\mathrm{P}<0.05)$.

Hormonally active forms of vitamin D mediate their effects via agonist action at VDRs, which are transcription regulators principally located in the nuclei of target cells. Vitamin D deficiency has been associated with muscle weakness $(6,7)$, predominantly type II fibre atrophy, accompanied by fibre necrosis and fatty infiltration. This may occur due to reduced calcium uptake by the sarcoplasmic reticulum and the impairment of glycolysis by phosphate depletion.

VDR polymorphisms are associated with differences in strength in premenopausal females. Furthermore, VDR expression levels reduce with age and VDR genotypes have been associated with fat-free mass and strength in elderly individuals (40). Few studies have specifically examined the association between VDR polymorphisms and exercise training, and to the best of our knowledge only one study has analyzed the association between VDR polymorphisms and football performance (23). A previous study (41) observed a significant increase in the expression levels of VDR at day 7 of muscle regeneration. These findings confirmed the expression of VDR in vivo and indicated that vitamin D may be involved in skeletal muscle regeneration following injury.

The present study identified no associations between the BsmI and FokI genotypes and the incidence or severity of MI. However, the ApaI polymorphism contributed significantly to the MI severity variance, suggesting that ApaI may affect the timing of skeletal muscle regeneration following injury. Studies involving larger cohorts are required to fully understand the association between VDR polymorphisms and the risk of MI in football players.

Therefore, the present study indicates the importance of the VDR ApaI polymorphism for the assessment of the risk of football players incurring musculotendinous injuries and to improve their recovery period following injury.

Predictive genomic DNA profiling for injury predisposition may be used by football professionals, in addition to other more common parameters, to aid in the formulation of personalized training to achieve optimal performance within safety limits for each athlete and to adopt individual protocols for the prevention of injury.

\section{Acknowledgements}

The authors would like to thank the players and staff of Cagliari Calcio SpA who participated in the present study and provided data over the four seasons.

\section{References}

1. Taymans SE, Pack S, Pak E, Orban Z, Barsony J, Zhuang Z and Stratakis CA: The human vitamin D receptor gene (VDR) is localized to region 12 cen-q12 by fluorescent in situ hybridization and radiation hybrid mapping: Genetic and physical VDR map. J Bone Miner Res 14: 1163-1166, 1999.

2. Pfeifer M, Begerow B and Minne HW: Vitamin D and muscle function. Osteoporos Int 13: 187-194, 2002.

3. Bartoszewska M, Kamboj M and Patel DR: Vitamin D, muscle function, and exercise performance. Pediatr Clin North Am 57: 849-861, 2010.

4. Pojednic RM and Ceglia L: The emerging biomolecular role of vitamin D in skeletal muscle. Exerc Sport Sci Rev 42: 76-81, 2014.

5. Habuchi T, Suzuki T, Sasaki R, Wang L, Sato K, Satoh S, Akao T, Tsuchiya N, Shimoda N, Wada Y, et al: Association of vitamin D receptor gene polymorphism with prostate cancer and benign prostatic hyperplasia in a Japanese population. Cancer Res 60: 305-308, 2000.

6. Janssen HC, Samson MM and Verhaar HJ: Vitamin D deficiency, muscle function, and falls in elderly people. Am J Clin Nutr 75: 611-615, 2002.

7. Bischoff-Ferrari HA, Borchers M, Gudat F, Dürmüller U, Stähelin HB and Dick W: Vitamin D receptor expression in human muscle tissue decreases with age. J Bone Miner Res 19: 265-269, 2004.

8. Glerup H, Mikkelsen K, Poulsen L, Hass E, Overbeck S, Andersen H, Charles P and Eriksen EF: Hypovitaminosis D myopathy without biochemical signs of osteomalacic bone involvement. Calcif Tissue Int 66: 419-424, 2000.

9. Bischoff HA, Stähelin HB, Dick W, Akos R, Knecht M, Salis C, Nebiker M, Theiler R, Pfeifer M, Begerow B, et al: Effects of vitamin D and calcium supplementation on falls: A randomized controlled trial. J Bone Miner Res 18: 343-351, 2003.

10. Kuchuk NO, Pluijm SMF, van Schoor NM, Looman CWN, Smit JH and Lips P: Relationships of serum 25-hydroxy vitamin D to bone mineral density and serum parathyroid hormone and markers of bone turnover in older persons. J Clin Endocrinol Metab 94: 1244-1250, 2009.

11. Annweiler C, Schott-Petelaz AM, Berrut G, Kressig RW, Bridenbaugh S, Herrmann FR and Beauchet O: Vitamin D deficiency-related quadriceps weakness: Results of the Epidemiologie De l'Osteoporose cohort. J Am Geriatr Soc 57: 368-369, 2009.

12. Bischoff-Ferrari HA, Dietrich T, Orav EJ, Hu FB, Zhang Y, Karlson EW and Dawson-Hughes B: Higher 25-hydroxyvitamin D concentrations are associated with better lower-extremity function in both active and inactive persons aged $>$ or $=60 \mathrm{y}$. Am J Clin Nutr 80: 752-758, 2004.

13. Wicherts IS, van Schoor NM, Boeke AJ, Visser M, Deeg DJ, Smit J, Knol DL and Lips P: Vitamin D status predicts physical performance and its decline in older persons. J Clin Endocrinol Metab 92: 2058-2065, 2007.

14. Bartali B, Frongillo EA, Guralnik JM, Stipanuk MH, Allore HG, Cherubini A, Bandinelli S, Ferrucci L and Gill TM: Serum micronutrient concentrations and decline in physical function among older persons. JAMA 299: 308-315, 2008.

15. Ekstrand $\mathbf{J}$ and Gillquist $\mathrm{J}$ : Soccer injuries and their mechanisms: A prospective study. Med Sci Sports Exerc 15: 267-270, 1983.

16. Inklaar H: Soccer injuries. I: Incidence and severity. Sports Med 18: 55-73, 1994.

17. Taimela S, Kujala UM and Osterman K: Intrinsic risk factors and athletic injuries. Sports Med 9: 205-215, 1990. 
18. Shindle MK, Voos JE, Gulotta L, Weiss L and Rodeo SA Kelly et al. Vitamin D status in a professional American football team. Presented at: American Orthopaedic Society for Sports Medicine, 2011. http://www.sportsmed.org/uploadedFiles/ Content/Medical_Professionals/Events/Meetings/Annual_ Meeting/AM_2011/PodiumAbstracts11.pdf

19. Maroon JC, Mathyssek CM, Bost JW, Amos A, Winkelman R, Yates AP, Duca MA and Norwig JA: Vitamin D profile in national football league players. Am J Sports Med: Feb 3, 2015 (Epub ahead of print).

20. Collins M and Raleigh SM: Genetic risk factors for musculoskeletal soft tissue injuries. Med Sport Sci 54: 136-149, 2009.

21. Maffulli N, Margiotti K, Longo UG, Loppini M, Fazio VM and Denaro V: The genetics of sports injuries and athletic performance. Muscles Ligaments Tendons J 3: 173-189, 2013.

22. Santiago C, González-Freire M, Serratosa L, Morate FJ, Meyer T, Gómez-Gallego F and Lucia A: ACTN3 genotype in professional soccer players. Br J Sports Med 42: 71-73, 2008

23. Micheli ML, Gulisano M, Morucci G, Punzi T, Ruggiero M, Ceroti M, Marella M, Castellini E and Pacini S: Angiotensin-converting enzyme/vitamin D receptor gene polymorphisms and bioelectrical impedance analysis in predicting athletic performances of Italian young soccer players. J Strength Cond Res 25: 2084-2091, 2011.

24. Eynon N, Ruiz JR, Yvert T, Santiago C, Gómez-Gallego F, Lucia A and Birk R: The C allele in NOS3 -786 T/C polymorphism is associated with elite soccer player's status. Int J Sports Med 33: 521-524, 2012.

25. Massidda M, Corrias L, Ibba G, Scorcu M, Vona G and Calò CM: Genetic markers and explosive leg-muscle strength in elite Italian soccer players. J Sports Med Phys Fitness 52: 328-334, 2012.

26. Pimenta EM, Coelho DB, Cruz IR, Morandi RF, Veneroso CE de Azambuja Pussieldi G, Carvalho MR, Silami-Garcia E and De Paz Fernández JA: The ACTN3 genotype in soccer players in response to acute eccentric training. Eur J Appl Physiol 112: 1495-1503, 2012

27. FicekK,CieszczykP,KaczmarczykM,Maciejewska-KarłowskaA, Sawczuk M, Cholewinski J, Leonska-Duniec A, Stepien-Slodkowska M, Zarebska A, Stepto NK, et al: Gene variants within the COL1A1 gene are associated with reduced anterior cruciate ligament injury in professional soccer players. J Sci Med Sport 16: 396-400, 2013.

28. Pruna R, Artells R, Ribas J, Montoro B, Cos F, Muñoz C, Rodas G and Maffulli N: Single nucleotide polymorphisms associated with non-contact soft tissue injuries in elite professional soccer players: Influence on degree of injury and recovery time. BMC Musculoskelet Disord 14: 221, 2013.

29. Egorova ES, Borisova AV, Mustafina LJ, Arkhipova AA, Gabbasov RT, Druzhevskaya AM, Astratenkova IV and Ahmetov II: The polygenic profile of Russian football players. J Sports Sci 32: 1286-1293, 2014.
30. Gineviciene V, Jakaitiene A, Tubelis L and Kucinskas V: Variation in the ACE, PPARGC1A and PPARA genes in Lithuanian football players. Eur J Sport Sci 14 (Suppl 1): S289-S295, 2014.

31. Massidda M, Scorcu M and Calò CM: New genetic model for predicting phenotype traits in sports. Int J Sports Physiol Perform 9: 554-560, 2014.

32. Massidda M, Corrias L, Bachis V, Culigioni C, Piras F, Cugia P, et al: Genetic polymorphisms and skeletal muscle injuries among Italian soccer players. Ann Sports Med Res 1: 1004, 2014

33. Massidda M, Bachis V, Corrias L, Piras F, Scorcu M and Calò CM: Influence of the COL5A1 rs12722 on musculoskeletal injuries in professional soccer players. J Sports Med Phys Fitness: Jan 13, 2015 (Epub ahead of print).

34. Pruna R, Ribas J, Montoro JB and Artells R: The impact of single nucleotide polymorphisms on patterns of non-contact musculoskeletal soft tissue injuries in a football player population according to ethnicity. Med Clin (Barc) 144: 105-110, 2015.

35. Chanock SJ, Manolio T, Boehnke M, Boerwinkle E, Hunter DJ, Thomas G,Hirschhorn JN, Abecasis G, AltshulerD, Bailey-Wilson JE, et al; NCI-NHGRI Working Group on Replication in Association Studies: Replicating genotype-phenotype associations. Nature 447: 655-660, 2007.

36. Fuller CW, Ekstrand J, Junge A, Andersen TE, Bahr R, Dvorak J, Hägglund M, McCrory P and Meeuwisse WH: Consensus statement on injury definitions and data collection procedures in studies of football (soccer) injuries. Br J Sports Med 40: 193-201, 2006.

37. Hägglund M, Waldén M, Bahr R and Ekstrand J: Methods for epidemiological study of injuries to professional football players: Developing the UEFA model. Br J Sports Med 39: 340-346, 2005.

38. Johnson A, Doherty PJ and Freemont A: Investigation of growth, development, and factors associated with injury in elite schoolboy footballers: Prospective study. BMJ 338: b490, 2009.

39. Rezende VB, Barbosa F Jr, Montenegro MF, Sandrim VC, Gerlach RF and Tanus-Santos JE: Haplotypes of vitamin D receptor modulate the circulating levels of lead in exposed subjects. Arch Toxicol 82: 29-36, 2008.

40. Bahat G, Saka B, Erten N, Ozbek U, Coskunpinar E, Yildiz S, Sahinkaya $\mathrm{T}$ and Karan MA: BsmI polymorphism in the vitamin $\mathrm{D}$ receptor gene is associated with leg extensor muscle strength in elderly men. Aging Clin Exp Res 22: 198-205, 2010.

41. Srikuea R, Zhang X, Park-Sarge OK and Esser KA: VDR and CYP27B1 are expressed in $\mathrm{C} 2 \mathrm{C} 12$ cells and regenerating skeletal muscle: Potential role in suppression of myoblast proliferation. Am J Physiol Cell Physiol 303: C396-C405, 2012. 